\title{
Fiberguide Device
}

National Cancer Institute

\section{Source}

National Cancer Institute. Fiberguide Device. NCI Thesaurus. Code C50362.

A device designed to assist in installation of fiberoptic cables. 